\title{
Competency Based Human Resource Management in Process Industries with Specific Reference to Bhilai Steel Plant
}

\author{
Jai Prakash Pandey ${ }^{1}$, Sanjay Guha ${ }^{2}$ \\ ${ }^{I}$ (DGM (Projects), SAIL, Bhilai Steel Plant, Bhilai, C. G., India) \\ ${ }^{2}$ (Professor and Head, Department of Management, BIT, Durg, C.G., India)
}

\begin{abstract}
In present business scenario, companies are required to be vigilant to changing customer needs and emerging market trends. Proactive action to align the organization to these changes can be a competitive advantage for the organization. More-over, the process industries have limitations of less flexible product mix and raw material which further put constraints on their profitability. Steel industry is no exception to it. Competency development plays a major role in fulfilling customer requirements with minimum cost. Competency based human resource management tries to orient HR processes and systems to enhance the capability of the people at workplace. Present research work employs literature and empirical study of the HRM practices at Bhilai Steel Plant which are aligned to develop competencies of the people. It can be inferred from the study that strategic management of human resources play significant role in developing competency required at work place.
\end{abstract}

Keywords: Competency, Customer, Cost, Organization, Proactive, Process, workplace.

\section{Introduction}

Organizations, today, are adopting growth strategies based on resources which are unique due to their inherent quality over their competitors. This becomes an asset to gain competitive edge and cope up with market dynamics from strategic point of view. People are one of the most important resources amongst organizational culture; reputation and relationship with stakeholders which are differentiating factor in today's market dynamics. It is the need of the present business scenario to evolve and realize that it is the people who can earn the brand name for the company and therefore, all necessary steps need to be taken for operationalizing the process of competence development and its management within their own organization.

Companies are coming to the conclusion that competencies can be used to overcome the financial turbulence and also at the time of market and financial stability and growth. Future success of the organization is analysed in light of state of the business in long run and accordingly key competencies, organizationally and individually, are assessed for future success. From strategic point of view, the companies have to differentiate themselves from their competitors and at the same time, achieve sustainable growth. They have to do so, on the basis of their capability to leverage their soft resources or asymmetries to their maximum potential. A study of a number of firms by Danny Miller [1] shows how some of the companies were able to build not so much on resources and capabilities as on asymmetries. Asymmetries are typically skills, processes or assets a firm's competitor do not and cannot copy on a cost that affords economic rents.

At the time of crisis in a particular location and situation, competencies are used to normalize it, but they are not propagated to other places and situations of works and therefore, they become past incidents in due course of time. Individual competency (dimensions of behavior lying behind a competent performer) alone does not yield results in totality in an organization. Workplace competence gives the desired result which generally emanates from group competency at which the person is competent to specific areas of work. It requires establishing of the process of building the competencies. A competency is a set of behaviour patterns that the incumbent needs to bring to a position in the order to perform its tasks and functions with competence [2]. Competency is more precisely defined as the behaviours that employees must have, or must acquire, to input into a situation in order to achieve high levels of performance, while 'competence' relates to a system of minimum standards or is demonstrated by performance and outputs [3]. Therefore, the notion of competence integrates attributes with performance [4]. Competence development is possible by identifying, developing and nurturing the competencies for realizing the competence at workplace.

In recent times, global industries like FMCGs, Finance and Banking, Automotive, White Goods, IT, Steel, Chemical and Fertilizers, Paper and Pulp and Leather have gone through the process of diversification, relocation and integration. Steel industries of South Korea and Europe are willing to invest into the Indian steel market and have started to make their presence felt. Merger of big companies in the global steel business and the capacity expansion in the domestic steel markets have brought the Indian and world steel industry at the same platform where measure of the bench mark will be same for domestic and international players. As a matter of fact, all these companies will have almost same process and equipments of world-class technology. In this 
perspective, competency based human resource management has to play a very important role for competitive advantage.

Bhilai Steel Plant (BSP), a flagship unit of SAIL is a learning organization and people competency as well as organizational competencies is given utmost importance which is seen mutually complementary. Adequate HR activities are in place to leverage soft skills and technical skills for deriving desired results by talent development and management to face the future challenges of capacity expansion. HR in BSP is playing a crucial role by integrating performance management, organizational structure, and different processes and systems to develop competencies in line with organizational goals and objectives.

The paper is intended to deal with the conceptual background of the competency and competence, and the significance of current HR practices in connection with competence development. The study focuses on key HRM issues like performance management, organizational structure, systems and processes in the use of competency-based models at Bhilai Steel Plant. It envisages to find out the relationship of these factors in competency based human resource management.

\section{Intellectual Asset Of A Company: Its Strategic Importance}

In present business environment, success of a company has greater dependency on intellectual assets as compared to their tangible resources [5], [6]. The main constituents of these assets include knowledge, skills and attitude of the workforce. It becomes endeavour of several organizations to find ways to get maximum benefit out of these assets.

To reap the benefit on consistent basis in the long run, organizations are trying to find ways to use the assets to secure a steady competitive advantage. Human expertise has got an important place among the elements of competence comprising company's systems, technologies, physical location and infrastructure, ever since the concept of "core competence" was propagated by Prahalad \& Hamel [7]. Therefore, managing individual competencies (knowledge and skills) is one important factor in dealing with the strategic competitive advantage. This requires that the individual competencies are in line with organizational core competence. From strategic management point of view, the individual competencies need to be enhanced by putting in focused efforts to devise workable instruments for competence development.

As a matter of fact, human resources management (HRM) has been the basic discipline concerned with carrying out these strategic objectives. The principal function of HRM is concerned with optimizing the workforce in line with company's goals and objectives. The conventional function includes job analysis, selection, training and development and the like as HRM instruments which have been in use in organizations for years. These instruments lack in connecting the HRM factors strategically and hence operationalizing of competence based HRM practices has been emphasized. It has also been expressed whether these instruments are able to cope with the new productivity challenge in the knowledge-based economy, namely to enhance the productivity of the knowledge workers who now make up a large share of the workforce [8].

Michellone and Zollo [9] emphasize that "the very paradox of knowledge is that firms possess knowledge only if they are able to transform it, and the primary ability to transform knowledge resides in people and their competencies." (p.137.). This has been agreed upon by the proponents of KM by putting an emphasis on implicit knowledge and the techniques necessary to deal with it from an organizational point of view.

It appears that these disciplines have tried their best to find out the ways to leverage human competencies in organizations in an effective manner. They have approached the issue from different perspectives and have used different methods and processes to deal with it. But it has been experience of the organizations that it is not so easy and they all have limitations as well. Competence management has been widely used for developing and putting right person at right place in some of the countries like US. Data of several surveys conducted between 1996 and 1998 reveal that, "75-80\% of responding companies have some competency-driven application in place "Schippman et al. [10].

The goal of competency-based human resource management targets for evolution and application of an instrument of competence development and talent management which alleviates some of the drawbacks of conventional approach of HRM. It focuses on connecting the competencies to actual performance in the workplace by studying current approaches of competence management and reviewing existing ones. It facilitates identification of the challenges and shortcomings that have not been sufficiently addressed for people management.

\section{Research Methodology}

There are two components to this study, that is, literature and empirical study. Empirical study is carried out by surveying a population of 98 frontline, middle and senior level executives at Bhilai Steel Plant. The survey instrument was designed to obtain broad perspective from areas of HR functions like performance management, structure, system and processes which facilitate optimum utilization of competencies to fulfil the company objectives. The respondents were asked to score on 5 point Likert scale (5- strongly agree, 4- agree, 3- 
neutral, 2- disagree, 1- strongly disagree). The percentage response and the weighted mean value against each questionnaire statement were tabulated and the data was analysed with the help of $f$ graph for finding out relationship between the variables.

\section{Result And Discussion}

From Table 1 and Fig.1, it is observed that Bhilai Steel Plant, over the years, has developed and set HR processes and systems which help to foster adequate level of competency of the individual and organization. HR Process and performance management have facilitated development of required and new competencies to a large extent with weighted mean of 3.5 and 3.2 respectively. Alignment of personal development goals with organizational goals, training delivery based on development need, competency based benefit, training needs identification, and structured methods of "need based learning have been adequately facilitated by HR processes performance management systems with scores of 3.4, 3.3, 3.1, 3 and 3 respectively. However, the influence of performance management and organizational development processes need to be further strengthened for competency mapping, making people realize their developmental needs and development of managerial and leadership skills, with scores of 2.5, 2.6 and 2.9 respectively. It is seen that the training imparted in the company right now are good enough but they need to be more focused and customized to managerial and leadership skills. Formal system with high level of expertise for competency mapping will yield further value for more realistic training need identification and genuine feedback.

Table 1: Role of HRM in Competence Building

\begin{tabular}{|c|c|c|c|c|c|c|c|}
\hline $\begin{array}{l}\text { Statem } \\
\text { ent No. }\end{array}$ & Statements & $\begin{array}{l}\text { Strongly } \\
\text { Agree } \\
(\%)\end{array}$ & $\begin{array}{c}\text { Agree } \\
(\%)\end{array}$ & $\begin{array}{c}\text { Neutral } \\
(\%)\end{array}$ & $\begin{array}{c}\text { Disagree } \\
(\%)\end{array}$ & $\begin{array}{l}\text { Strongly } \\
\text { Disagree } \\
(\%) \\
\end{array}$ & $\begin{array}{l}\text { Wtd. Avg. } \\
\text { ( } 1 \text { to } 5 \\
\text { scale) }\end{array}$ \\
\hline 1 & $\begin{array}{l}\text { HR Process is aimed at developing people } \\
\text { to help them acquire new and required } \\
\text { competence }\end{array}$ & 20 & 37 & 26 & 10 & 7 & 3.5 \\
\hline 2 & $\begin{array}{l}\text { organization has structured methods of } \\
\text { "need based learning (Learning when you } \\
\text { need it) }\end{array}$ & 13 & 20 & 37 & 13 & 17 & 3 \\
\hline 3 & $\begin{array}{l}\text { organization has established methods of } \\
\text { mapping competencies of people }\end{array}$ & 7 & 13 & 27 & 26 & 27 & 2.5 \\
\hline 4 & $\begin{array}{l}\text { Performance management system actively } \\
\text { encourages people to develop competencies }\end{array}$ & 26 & 20 & 16 & 22 & 16 & 3.2 \\
\hline 5 & $\begin{array}{l}\text { The performance management system } \\
\text { actively facilitates the development of both } \\
\text { managerial and leadership skills in the } \\
\text { employees. }\end{array}$ & 16 & 20 & 20 & 24 & 20 & 2.9 \\
\hline 7 & $\begin{array}{l}\text { The existing performance management } \\
\text { system provides for a competency based } \\
\text { benefit }\end{array}$ & 27 & 20 & 13 & 20 & 20 & 3.1 \\
\hline 8 & $\begin{array}{l}\text { Organization helps people to realize their } \\
\text { developmental needs. }\end{array}$ & 7 & 13 & 33 & 27 & 20 & 2.6 \\
\hline 9 & $\begin{array}{l}\text { HR process enables alignment of personal } \\
\text { development goals with organizational } \\
\text { goals. }\end{array}$ & 20 & 35 & 20 & 15 & 10 & 3.4 \\
\hline
\end{tabular}




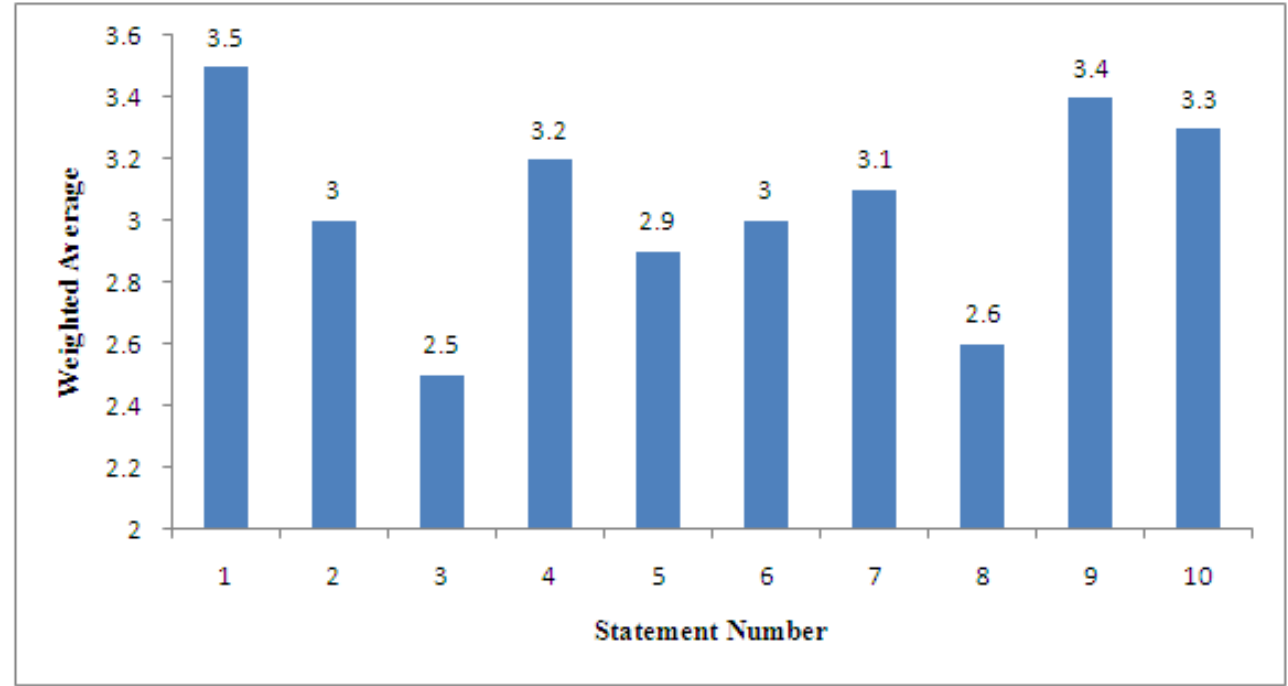

Fig. 1: Role of HRM in Competence Building

\section{Conclusion}

Human resource management at Bhilai Steel Plant has facilitated in meeting the challenges of the changing environment, nationally and globally, by developing and sustaining the new competencies. Further, it has always nurtured processes and systems that help in competence building which makes creative impacts at the workplaces. Alignment of HR policy, strategies and action plans with organizational strategies, structures and processes has led to sustained improvements in people competency and motivation. There are robust HR structure; processes and performance management system, well in place, in Bhilai Steel Plant, which have the potential to further contribute in taking proactive action for strengthening interventions like competency mapping, identifying development needs and enhancing managerial skills of the workforce to meet the future challenges of managing projects, quality control, working with high degree of automation and to take risk on the job.

\section{References}

[1]. Miller, Danny. 2003. Strategic Management Journal, vol. 24, Issue 10, pg. 961, Chichester.

[2]. Woodruffe, C. 1992. What is meant by a competency?. In R. Boam and P. Sparrow (eds), Designing and Achieving Competency. Maidenhead: McGraw-Hill, pp 16-29.

[3]. CIPD. 2009. Competency and frameworks. http://www.cipd.co.uk/subjects/perfmangmt/competnces/comptfrmwk.htm?IsSrchRes=1

[4]. Gonzi, A., Hager, P., \& Athanason, J. 1993. The development of competency-based assessment strategies for the professions. National Office for Overseas Skills Research Paper No. 8. Canberra, Australia: Australian Government Publishing Service.

[5]. Sveiby, K. E. 1997. The New Organizational Wealth. San Francisco: Berrett-Koehler.

[6]. Stewart, T. A. 1997. Intellectual capital: the new wealth of organizations. New York: Doubleday.

[7]. Prahalad, C., \& Hamel, G. 1990. The Core Competence of the Corporation. Harvard Business Review, 68(3), 79-91. Probst, G.

[8]. Elkjaer, B. 2000. Learning and getting to know: the case of knowledge workers. Human Resource Development International, 3(3), 343-359.

[9]. Michellone, G., \& Zollo, G. 2000. Competencies management in knowledge-based firms. International Journal of Technology Management, 20(1/2), 134-155. 55.

[10]. Schippman, J. S., Ash, R. A., Battista, M., Carr, L., Eyde, L. D., Hesketh, B., Kehoe, J., Pearlman, K., Prien, E. P., \& Sanchez, J. I. 2000. The practice of competency modelling. Personnel Psychology, 53, 703-740. 